\title{
REGULATIONS OF PUBLIC FOOD PROCUREMENT: OPPORTUNITIES AND CHALLENGES
}

\author{
Inita Krivašonoka \\ Latvia University of Agriculture \\ inita.krivasonoka@gmail.com
}

\begin{abstract}
Public food procurement is a complex system with a large number of participants, and it is regulated by a number of laws and regulations on different sectors, and there is involved a number of controlling bodies. The research aim is to explore and analyze the laws and regulations governing public food procurement in Latvia and to identify the main obstacles to food purchases from local producers. By purchasing food, local governments or authorities have to fulfill the European Union (EU) and the Latvian statutory requirements for both the correct procurement procedures, both on food safety and hygiene norms throughout the whole food product life cycle.

Purchasing food from local producers is a challenge, because on the one hand, the EC Treaty and a number of other documents request the free movement of goods and equal rights for all market participants, on the other - the local community and local government is interested in providing school students with high-quality, natural food and in promoting small local businesses.

The solution is to use green public procurement (GPP) criteria in the public food procurement. However, in the implementation of the GPP there are several disadvantages for both the local government and local food producers. By studying Latvian and other EU countries' experiences, it can be concluded that barriers to local food producers to participate in local government food procurement are related to both competitiveness and production storage and regular supply assurance.
\end{abstract}

Key words: Local food, public procurement, regulations.

\section{Introduction}

There exists the belief that a healthy diet is the basis for sustainable development because it improves both the health of the population and the environment and social justice (Morgan \& Sonnino, 2010).

When there is a talk of a market for high quality foods, schools are not usually identified as the target market. However, school food is essential supply chain, in which priority is given to high-quality fresh, locally produced food (Sonnino, 2009).

Healthy and high-quality diet has the decisive role in ensuring and improving health indicators. In order to ensure the mental and physical health, children must have a balanced, natural, healthy and wholesome diet. A large part of the day children are spending in kindergartens or schools, so it is essential that the received meals in the education institutions provide children with the all necessary nutrients. Children who do not receive adequate nutrition or receive it insufficient are unable to concentrate and participate fully in the learning process; they are often sick and quickly get tired.

Catering service in the educational institution is provided by the local authority or by the educational institution to which that function has been delegated. It plans and prepares the food service or food purchase procurement documentation and selects the appropriate tenderers. Quality of prepared procurement documentation and professionalism and knowledge of Procurement Commission affects the quality of provided catering service in the education institution a lot.
Also, in order to supply high-quality food and food products to schools and kindergartens in the planning of procurement, it is essential to ensure appropriate and sufficient funding. Lowest price cannot be put forward as the sole criterion for selecting suppliers of foodstuffs or food service providers, because it does not provide the necessary food quality. It is also important to promote the purchase of local products through the laws and regulations to ensure that fresh, high-quality products from local producers are included in the menu.

In many cases, the main emphasis in school nutrition is on cost reduction rather than on a more comprehensive approach that includes quality, nutritional value and sustainability. This economic focus leads to many difficulties faced by most responsible food service providers in schools. Despite these problems, many local authorities evaluate the food system and, through innovative approaches, seek to ensure that school food quality and sustainability is still high (INNOCAT, 2015). For example, in one of French municipalities it was indicated that 20 percent of school food must be organically grown (European Commision, 2014).

The research aim is to explore and analyze the laws and regulations governing public food procurement in Latvia and to identify the main obstacles to food purchases from local producers. Research tasks: To identify the EU legislation governing procurements and food safety, analyze the Latvian legislation applicable to food purchasers, as well as to explore the burdens and opportunities for procuring local production for educational institutions. 


\section{Materials and Methods}

The following research methods were employed to carry out the present research: induction and deduction, analysis and synthesis, the monographic method, the analysis of documents and survey method. A study on food procurement legislation was made at the beginning of 2017 (January-February), but the survey was conducted in 2014, from September to December.

The paper employed theoretical findings of scientists, the legal frameworks of Latvia and the EU that set the standards on purchasing food and standards on food safety.

\section{Results and Discussions}

Public procurement is important as one of the market instruments to be used to achieve the targets of the EU strategy Europe 2020 (Europe 2020, 2010). In particular, through public procurement, the strategy Europe 2020 encourages to:

- support transition to an economy that saves resources and produces low carbon dioxide emissions, for instance, by encouraging wider use of green public procurement,

- improve the entrepreneurship environment, especially for innovative small and medium enterprises (Green Book, 2011).

The role of the public sector in stimulating sustainable development has been in the spotlight of many researchers. Sustainable procurement is based on the basic principles of sustainable development, that is, it is environmentally friendly as well as promoting a healthy and strong society and social justice (Walker \& Brammer, 2009; Rimmington et al.,
2006). Public procurement is complex because, on the one hand, it is necessary to ensure competitiveness and free trade criteria, on the other hand, there should be included environmental sustainability and social ideal-providing criteria (Morgan \& Sonnino, 2007).

The Operational Strategy 2014 - 2016 of the Ministry of Agriculture of the Republic of Latvia aimed to support agricultural industries producing higher value-added products being demanded in the domestic and foreign markets as one of the priorities in this period (including local food producer quality schemes and organic farming). In this context, one of the most important medium-term tasks is the promotion of production and consumption of local food through implementing measures aimed at increasing the market share of food products produced in Latvia in public procurement and consumption, continuing implementing informative and promotional food programs and improving food quality schemes (Ministry of Agriculture, 2014).

Europe 2020 stresses that public procurement policies have to guarantee as efficient use of public funds as possible as well as procurement markets have to be accessible at EU scale.

Researching regulations of public food procurement, they should be divided into two broad categories:

1. Laws and regulations of the public procurement;

2. Food safety and hygiene laws.

Figure 1 schematically depicts the structure of public food procurement in Latvia, including regulatory hierarchy and structure, as well as food chain controlling authorities.

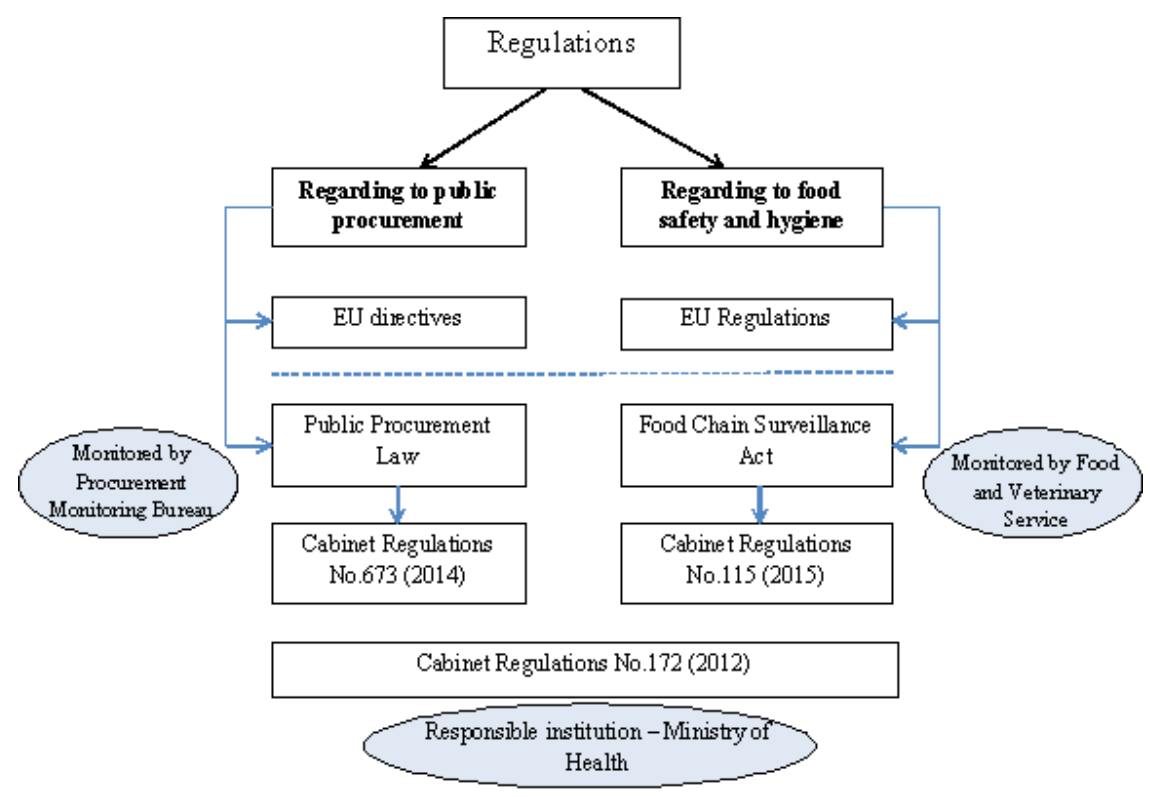

Figure 1. Public food procurement regulatory laws and controlling institutions.

(Source: Author's scheme). 
As shown in Figure 1, Latvian public food procurement system is a complicated complex monitored by a number of institutions that are responsible both for the procurement procedure observance, both for food safety and hygiene requirements throughout the food chain.

\section{Laws and regulations of the public procurement}

The Treaty establishing the European Community in 1957 introduced the principle of a 'single market' and a single Europe for the first time. The Treaty actually sought to ensure a European-scale commitment to free flows of goods among countries and a commitment to economic growth in all the Member States, based on trade among countries. In accordance with this principle regarding the single market, the Treaty, in fact, bans anti-competition in procurement, which would be beneficial to national or local suppliers (Jackson, 2010).

EU regulations, regarding public procurement, are often mentioned as an obstacle to school food reform. The US procurement rules are also interpreted as a barrier for the purchasing of local products in school lunches because they, as well as EU legislation requires that tenders are not allowed to give priority to regional manufacturers. However, compared to Great Britain and France approach to procurements, both of which comply with the rules laid down in the EU, it is clear that this problem is only interpretation. The EU procurement laws and regulations are not barriers to implementation of sustainable procurement, unless the national and local authorities have the competence and confidence to do it under these rules (Morgan \& Sonnino, 2007; Garnett, 2007).

The current public procurement Directives 2014/24/EU and 2014/25/EU, which repealed Directive 2004/18/EC and 2004/17/EC, are the latest stage of public procurement development, which began in 1971 with the adoption of Directive 71/305/ EEC. The aim of this Directive is mainly to ensure that economic operators benefit fully from the basic freedoms in public procurement by guaranteeing usage of transparent and non-discriminatory procedure. The current Directives also mention a number of objectives with regard to other policies, such as environmental and social standards integration of this system. Directive 2014/24/EU underlines that public procurements must comply with the principles of Treaty on European Union, and in particular the principle of free movement of goods, freedom of establishment and freedom to provide services.

Latvian public procurement system is being developed and improved since the very beginning of the Latvian state. Consequently, with the Latvia's objective - joining the EU - it has been purposefully adapted to the European Union public procurement process regulatory directives: 92/50/EEC, 93/36/ EEC, 93/37/EEC, 93/38/EEC, 97/52/EC, 98/4/EC, but later $-2004 / 18 / \mathrm{EC}$ and 2004/17/EC.

In Latvia, public procurement was regulated by the Public Procurement Law of 2006. From March 1, 2017 it is replaced with a new law. In new law there are significant improvements and amendments to include requirements of Directives 2014/24/EU and 2014/25/EU. Purchases carried out in accordance with the laws and regulations are regulated by the Procurement Monitoring Bureau. Its goal is the implementation of public administration functions under the supervision of the procurement procedure. Its main function is to monitor if the procurement procedures carried out by governments, public service providers, public partners and public partners' representatives are in line with the statutory requirements (Cabinet of Ministers ..., 2004).

The purpose of public procurement is to guarantee the transparency of procurement procedures, free competition among suppliers as well as the efficient use of national and local government funding, maximally reducing the commissioning party's risks (Publisko iepirkumu..., 2017).

The Public Procurement Law stipulates that in order to compare and evaluate bids, the commissioning party selects one of the following criteria:

1. bids at the lowest price;

2. the most economically beneficial bid, taking into consideration the terms of delivery of supplies or the contractual deadline; exploitation costs and other costs, their efficiency; quality of goods, services or construction works; esthetical and functional characteristics; compliance with the environmental standards; technical advantages, availability of spare parts, security of supplies; price and other contract-related factors.

Previous experience in Latvia shows that for the purpose of efficient use of funding, mostly the lowest price criterion is employed in evaluating bids in municipal public food procurement.

According to research studies, price is the decisive factor in public catering. Financial pressure is the most important obstacle in implementing sustainable public procurement (Walker \& Brammer, 2009). Local producers have the same conditions in public procurement and they must compete with large food manufacturing companies and wholesalers. But the problem is that they cannot win because, on the whole, the costs of local food and therefore the price are higher, given the small production quantities.

For these reasons, local food producers have to be encouraged through various extra conditions, so that they remain competitive in procurement, for 
instance, through setting economic benefit criteria for evaluating the offers of bidders.

Preference may be given to the food produced in Latvia if successfully employing the criteria of the most economically beneficial bid. Such criteria can involve, for instance, price, quality, terms of delivery, life cycle cost or environmental values. The Law allows taking into account environmental issues, which enables the purchaser, i.e. the municipality to require short supply chain products.

In recent years, the principle of 'green procurement' has become increasingly important in Latvia. It involves the systematic integration of environmental (and social) criteria into all procurement-related activities for goods and services. It is one of the environmental policy instruments aimed at reducing the effect on the environment, achieving social improvements as well as saving funding (Procurement Monitoring ...., 2015).

GPP has become an environmental policy cornerstone at EU and national levels (Tukker et al., 2008). Since the international conference on the environment and development in Rio de Janeiro in 1992, the understanding of the role of GPP in sustainable consumption and production patterns has significantly improved, and now government institutions use it both as a policy instrument and as a technical tool (Testa et al., 2012).

Green public procurement is an instrument that directly stimulates and ensures increases in sales of local food. Making a public procurement contract in accordance with the GPP principles means that one can be sure that the goods or services purchased make the smallest effect on the environment and a positive social impact. Therefore, the choice of food products plays a significant role in reducing the effect on the environment and maintaining human health.

In Latvia, at the end of 2014, in response to Russia's embargo on the Latvian-produced food products and to promote local food consumption in the country, Cabinet Regulations No 673 'Regulations on the application of environmental criteria and establishment of criteria for selection of for the food supply and food service procurement' were accepted. These Regulations prescribe the requirements for public procurement using environmental criteria, and their application, as well as the applicable tender selection criteria for the food supply and catering contracts. Regulations are related to food supply and catering contracts.

These Regulations emphasize the following principles of GPP in purchasing of food products:

1. The products comply with organic farming or national food quality schemes or its product quality indicators, or integrated production requirements of agricultural products;
2. products which do not contain genetically modified organisms, do not either consist of GMOs or are produced from them;

3. preferred fresh and seasonal foods;

4. The products are purchased by the largest packaging or in packaging that is environmentally friendly or most of which is recyclable, or adopting for re-use;

5. Use of environmentally friendly supplies to reduce environmental pollution by motor exhaust fumes and road infrastructure load.

Similarly, the contracting authority may provide the food supply, the production of which is not used for a certain type of food coloring.

GPP as one of the national priorities is also addressed in other government policy documents and legal acts, which sets high quality standards for food supplies, stating that priority has to be given to the food products complying with the quality standards set in legal acts concerning the national food quality scheme or the organic farming scheme (Cabinet of Ministers, 2012).

After the entry into force of these Regulations GPP criteria in the procurement of food products increased, but still, their share is about $50 \%$ of the EU average (Procurement Monitoring ..., 2015).

\section{Food safety and hygiene laws}

European food safety policy has two objectives:

1. to protect human health and the interests of consumers;

2. to promote the smooth functioning of the EU market.

After the reform of the EU food safety policy approach "from farm to fork" was defined, guaranteeing a high level of safety for all available foods in EU market at all stages of the production and distribution, regardless of whether these products are produced in the EU or imported from third countries. This package consists of a complex and integrated system of rules that covers the whole food chain (European Parliament, 2016).

The general principles of food legislation came into force in 2002 (Regulation (EC) No. 178/2002). In this Regulation, there are general rules for food and feed traceability.

Other EU legislation, depending on the areas in which they govern, is divided into:

1. Food hygiene ((Regulation (EC) No. 852/2004 on the hygiene of foodstuffs, Regulation (EC) No. 853/2004, laying down specific hygiene rules for food of animal origin, and Regulation (EC) No. 854/2004, on which specific provisions relating to fresh meat, shellfish, milk and milk products) lays down.

2. Food contamination 
a. Food safety (Council Regulation (EEC) No. 315/93, which ensures that in the market there are not placed foods that contain unacceptable amounts of pollutants. Complementary regulation - Council Regulation (EEC) No. 1881/2006, fixing certain levels for contaminants in food);

b. Maximum residue levels (Regulation (EC) No. 396/2005 on pesticide residue limits in agricultural products, Regulation (EC) No. 37/2010 - on residues in animals);

c. Contamination from materials in contact with food (Regulation (EC) No. 1935/2004 emphasizes the main requirements for all materials and articles in contact with food).

3. Food labeling

a. Food labeling (Regulation (EC) No. 1169/2011 on the labeling, presentation and advertising, as well as on nutrition labeling for foodstuffs);

b. Nutrition and health claims (Regulation (EC) No. 1924/2006 governing the use of nutrition and health claims made on foods).

Food quality and safety in Latvia is regulated by the Food Chain Surveillance Act. Its goal is to provide quality and human health, life and environmentfriendly food chain, eliminating the risk and facilitating trade and protecting consumer interests. The law stipulates both requirements for food businesses and food quality and safety requirements.

The Ministry of Health develops and coordinates nutrition policy, approves the recommended nutrition standards and dietary guidelines for Latvian population, approves the nutritional standards for universal primary education, secondary education and vocational training institutions, as well as for preschool education programs, long-term social care and social rehabilitation institutions clients and inpatients.

Food and Veterinary Service, which is the national regulatory authority under the supervision of the Ministry of Agriculture is responsible for food monitoring and control in Latvia.

The main tasks of Food and Veterinary Service on the supervision of the Food Chain:

- to monitor and control of food products conformity with the regulatory requirements throughout the food chain;

- to recognize and register food business activities, as well as to withdraw their recognition and registration;

- monitoring and control of food businesses and food processes if they are consistent with the statutory requirements throughout the food chain;

- take risk research and analysis throughout the food chain;
- to monitor and control of observation of EU legislation requirements in food chain as well as to provide the necessary information to the European Union institutions;

- to monitor and control food contact materials in the production, processing and distribution processes (Pārtikas aprites ..., 2015).

According to the Food Chain Surveillance Act, new Cabinet Regulations No 115 was adopted in 2015 'Requirements for pre-packaged food labeling'. They set out the general requirements for the provision of information on food products; there are included requirements for nutrition and health claims, as well as requirements on indications or marks identifying the food product batch.

\section{Opportunities and challenges}

Latvian Rural Advisory and Training Centre, which is the largest consulting provider in Latvia, in 2014 surveyed education authorities in order to identify the situation of local public food procurement in Latvia. In total, there are 110 counties in Latvia. The study surveyed educational institutions in 99 counties (that is $90 \%$ of all counties) in which the Latvian Rural Advisory and Training Centre has regional branches.

The 99 districts surveyed have 835 municipal education institutions in total (Central Statistical Bureau, 2014). The survey questionnaire was sent to randomly select 697 educational institutions (to survey at least $80 \%$ of all educational institutions). The questionnaire responses provided by 315 educational institutions represented $37.7 \%$ of all educational institutions in the surveyed counties. In questionnaire, there were asked questions about the type of procurement (food or food service procurement), supplier selection criteria (lowest price or most economically advantageous tender), and local government willingness to purchase products from local producers.

From the institutions that responded on questionnaire $72 \%$ admitted that a key principle of procurement to determine the winner is the lowest price principle, and only $28 \%$ used the economically most advantageous tender criteria. The study revealed that only $37 \%$ of respondents used green procurement conditions because a large proportion of municipal procurement professionals do not have a clear understanding of exactly what it is. There is a perception - it is a biological production, which raises the costs of it (Rural Advisory ..., 2014). This indicates that many local governments and their institutions are still unclear about green procurement, there is lack of information what is included in it. Sometimes there is also an unwillingness to understand how it can be successfully applied in favor of local producers. 
The positive trend is that in the survey $91 \%$ of the institutions expressed readiness to choose local food in procurement and implement GPP criteria if there would be given different types of support, such as information of experience of other local government in buying local food, suppliers identification, as well as training on development of GPP.

The main obstacles that make it difficult for local small-scale producers to participate in local government procurement are following:

- small producers are not competitive to participate in the public procurement of food, where the lowest price is still the main criterion rather than the most economically advantageous tender because local producers cannot compete with wholesalers;

- Purchases basically are announced in the summer, when the harvest is already growing and the owners have already found purchasers for it;

- small producers do not have sufficient and high-quality space for vegetable storage until the next harvesting season;

- Complications are often in intended product range in procurement parts and delivery terms. It is being dealt with by dividing the lots in such a way that products that can be grown in Latvia and supplied by local farmers are separated from exotic fruits.

- This in turn leads to greater administrative burdens for school representatives, so not always procurement dividing in parts is introduced;

- It would be easier for suppliers to offer their products through the cooperation. However, it is difficult for the small farm owners to find leaders who would take the lead, and they must also deal with a relatively large distances to be taken by providing the product supply (Rural Advisory ..., 2014).

Exploring other EU countries' experiences, it can be concluded that there also has similar barriers to successful implementation of GPP. In addition, other countries have been identified other encumbrances of local entrepreneurs to participate in public food procurement:

- The price paid by the institutions is low;
- The quantity of products required by the body is inadequate for manufacturer (too big or too small);

- Expensive insurance premiums for the tender;

- Smaller companies have uncertainties with regard to access to procurement and tendering process by itself can be a burden;

- Lack of knowledge on how to sell their products to schools and other local authorities (Rosenberg et al., 2014; Pinard et al., 2013; Conner et al., 2012; Scottish Government, 2009).

Thus, studying the experience of other countries and actions to reduce these barriers, there is a possibility to incorporate requirements that promote the effective implementation of GPP in the Latvian laws and procurement regulations.

\section{Conclusions and Proposals}

Healthy and high-quality diet has the decisive role in ensuring and improving health indicators. Catering service in the educational institution is provided by the local authority or by the educational institution to which that function has been delegated. Quality of prepared procurement greatly affects the quality of provided catering service in the education institution.

Latvian public food procurement system is a complicated complex monitored by a number of institutions that are responsible for the procurement procedure observance, both for food safety and hygiene requirements throughout the food chain.

Purchasing food from local producers is a challenge because, on the one hand, the EC Treaty and a number of other documents request free movement of goods and equal rights for all market participants, on the other hand, the local community and local government is interested in providing school students with high-quality, natural food and promoting small local businesses. The solution is to use GPP criteria in the public food procurement.

Exploring Latvia's and other EU countries' experiences, it can be concluded that there are identified several burdens of local food producers to participate in local government organized food procurement that are related to both competitiveness and production storage and regular supply assurance.

\section{References}

1. Cabinet of Ministers of the Republic of Latvia. (2012). Cabinet Regulation No.172 'Noteikumi par uztura normām izglītības iestāžu izglītojamiem, sociālās aprūpes un sociālās rehabilitācijas institūciju klientiem un ārstniecības iestāžu pacientiem' (Regulations Regarding Nutritional Norms for Educatees of Educational Institutions, Clients of Social Care and Social Rehabilitation Institutions and Patients of Medical Treatment Institutions). Retrieved February 21, 2017, from: https://likumi.lv/doc.php?id=245300. (in Latvian).

2. Cabinet of Ministers of the Republic of Latvia. (2014). Cabinet Regulation No. 673 'Noteikumi par vides kritēriju piemērošanu un piedāvājuma izvēles kritēriju noteikšanu pārtikas produktu piegādes un ēdināšanas 
pakalpojumu iepirkumiem'. (Regulations on the application of environmental criteria and establishment of criteria for selection of for the food supply and food service procurement). Retrieved November 28, 2016, from: https://likumi.lv/doc.php?id=269980. (in Latvian).

3. Central Statistical Bureau (2014). Data on Educational institutions in Latvia regions. Retrieved September 2, 2014, from: http://data.csb.gov.lv/pxweb/lv/Sociala/Sociala_ikgad_izgl/?tablelist=true\&rxid=.

4. Conner, D.S., \& Levine, R. (2007). Circles of Association: The Connections of Community-Based Food Systems. Journal of Hunger and Environmental Nutrition, Vol. 1, pp. $5-25$.

5. European Commission. (2014). Organic Food Procurement for School Catering Services. GPP In practice. No. 41. Retrieved January 17, 2017, from: http://ec.europa.eu/environment/gpp/pdf/news_alert/Issue41_ Case_Study87_Lens_catering.pdf.

6. European Parliament. (2016). Information on EU food safety policy. Retrieved February 12, 2017, from: http://www.europarl.europa.eu/atyourservice/lv/display Ftu.html?ftuId=FTU_5.5.5.html.

7. Europe 2020. (2010). A Strategy for Smart, Sustainable and Inclusive Growth. COM (2010) 2020 final, Brussels, 3.3.2010a. Retrieved March 01, 2017, from: http://eur-lex.europa.eu/LexUriServ/LexUriServ. do?uri= COM:2010:2020:FIN: LV:PDF.

8. Garnett, S. (2007). School Districts and Federal Procurement Regulations. Alexandria, VA: Food and Nutrition Service, U.S. Department of Agriculture. Retrieved January 17, 2017, from: https://dpi.wi.gov/ sites/default/files/imce/school-nutrition/pdf/07_02farm.pdf.

9. Cabinet of Ministers of the Republic of Latvia. (2004). Cabinet Regulation No. 893 Iepirkumu uzraudzības biroja nolikums. (Procurement Monitoring Bureau Regulations). Retrieved December 15, 2016, from: https://likumi.lv/doc.php?id=95643. (in Latvian).

10. Procurement Monitoring Bureau. (2015). Zaļais iepirkums. (Green public procurement). Retrieved February 21, 2017, from: http://www.iub.gov.lv/node/61. (in Latvian).

11. INNOCAT. (2015). Sustainable Public Procurement of School Catering Services. A good practice report. Retrieved February 21, 2017, from: http://www.sustainable-catering.eu/fileadmin/user_upload/ InnocatReportFINAL_interactive.pdf.

12. Jackson, M. (2010). Making the Most of Public Sector Spend: Procurement as Local Economic Activism. Centre of Local Economic Strategies, Briefing. Retrieved February 12, 2017, from: http://www.cles.org. uk/wp-content/uploads/2011/01/Procurement-as-local-economic-activism.pdf.

13. Rural Advisory and Training Centre. (2014). Survey of educational institutions. Unpublished data, Rural Advisory and Training Centre, Latvia.

14. Morgan, K., \& Sonnino, R. (2007). Empowering Consumers: the Creative Procurement of School Meals in Italy and the UK. International Journal of Consumer Studies, Vol. 31 No. 1, pp. $19-25$.

15. Morgan, K., \& Sonnino, R. (2010). Rethinking School Food: The Power of the Public Plate. New York: The Worldwatch Institute.

16. Pārtikas aprites uzraudzības likums. (2015). (Food Chain Surveillance Law). Retrieved February 12, 2017, from: https://likumi.lv/doc.php?id=47184. (in Latvian).

17. Pinard, C.A., Smith, T.M., Carpenter, L.R., Chapman, M., Balluff, M., \& Yaroch, A.L. (2013). Stakeholders' Interest in and Challenges to Implementing Farm-to-School Programs, Douglas County, Nebraska, 2010 2011. Preventing Chronic Disease, Volume 10.

18. Publisko iepirkumu likums. (2017). (The Public Procurement Law). Retrieved March 11, 2017, from: https://likumi.lv/doc.php?id=287760. (in Latvian).

19. Rimmington M., Carlton Smith, J., \& Hawkins, R. (2006). CSR and Sustainable Food Procurement. British Food Journal, Vol. 108 No. 10, pp. $824-837$.

20. Rosenberg, N., Truong, N.L., Russell, T., Abdul-Haqq, D., Gipson, J.A., \& Hickson, D.A. (2014). Farmers' Perceptions of Local Food Procurement, Mississippi, 2013. Preventing Chronic Disease, Volume 11.

21. Scottish Government. (2009). Public Sector Food Procurement in Scotland: An Overview of Current Evidence. Retrieved March 11, 2017, from: http://www.gov.scot/resource/doc/277249/0083244.pdf.

22. Sonnino, R. (2009). Quality Food, Public Procurement and Sustainable Development: The School Meal Revolution in Rome. Environment and Planning. Vol. 41, No. 2 (2009), pp. 425 - 440.

23. Testa, F., Iraldo, F., Frey, M., \& Daddi, T. (2012). What Factors Influence the Uptake of GPP Practices? New Evidence from an Italian Survey. Ecological Economics, 82 (2012), pp. 88 - 96.

24. Tukker, A., Emmert, S., Charter, M., Vezzoli, C., Sto, E., Andersen, ... Lahlou, S. (2008). Fostering Change to Sustainable Consumption and Production: an Evidence Based View. Journal of Cleaner Production, 16, pp. $1218-1225$. 
25. Walker, H., \& Brammer, S. (2009). Sustainable Procurement in the United Kingdom Public Sector. Supply Chain Management: An International Journal, Vol. 14 No. 2, pp. 128 - 137.

26. Ministry of Agriculture. (2014). Latvijas Republikas Zemkopības ministrijas Darbības stratēǵija 2014. -2016. gadam (Latvia's Ministry of Agriculture Operational Strategy 2014 - 2016). Retrieved November 28, 2016, from: https:/www.zm.gov.lv/public/files/CMS_Static_Page_Doc/00/00/00/70/08/ Pielikums_ZM_rikojumam.pdf. (in Latvian). 